\title{
Financing Value Chains for Developing Rural Livelihoods
}

\author{
Spondon Borbora \\ Research Scholar, Department of Business Administration, Tezpur University \\ Prof. Debabrata Das \\ Department of Business Administration, Tezpur University
}

\begin{abstract}
:
The aim of the paper is to find out the critical points in value chain practice existing in rural farm and nonfarm sectors. The paper tries to find out a possible solution so that these value chains can be linked to financial service providers for the betterment of the rural mass. It is perceived that strengthening the value chain as well as promoting coordination between public and private players' results in benefitting the farmers and workers of rural areas. Financing the agricultural value chains means that small holders can have ready financial products available to invest in their value chain. Careful analysis and selection of value chains can contribute to identify opportunities for inclusive growth of small holders. In Assam, agricultural farmers sell to the nearest dealer/buyers and mostly immediately after harvesting when the price is at the lowest (Bhuyan, 1990; Bhuyan, et al., 1990). They do not get the return they should have earned. Therefore, access to market acts as constrain for their growth. The present study wants to bring out the directions in which the policy makers can focus to impose financial activity on value chain practices to strengthen the rural livelihoods.
\end{abstract}

\section{Key Words:}

Livelihoods, Value Chain, Microfinance, Rural Poor, Market Linkage

\subsection{Introduction:}

Poor livelihood is a national problem in India but the problem has assumed greater significant in Assam due to the economic backwardness of the State. Due to the incidences of underemployment or seasonal unemployment the effect is more pronounced in the rural areas of Assam (India Development Report 2011). When we talk about livelihoods and fighting for survival some interesting facts about India as well as the North Eastern Region specially Assam come to the picture. India is one of the fastest growing economies with annual growth rate of GDP of around $8 \%$ in the recent past. In spite of this rapid growth $41.80 \%$ of the rural population still lives below the poverty line (Tendulkar committee report 2004-05), which means they are not getting the proper livelihood. The situation is rather interesting in the North Eastern Region (NER). North East India, the land of opportunities, due to its rich natural resources, the region had attracted a lot in migration and huge investments. But the region is poor in infrastructure, especially in transport and communications, limited access to the outside world and markets. Almost $60 \%$ of north-east India is poor as per the MPI (Multi-dimensional Poverty Index) Developed by the Oxford Poverty and Human Development Initiative (OPHI) for the United Nations Development Programmes (UNDP). However, in recent years, the Government has been attending proactively to the 
development needs of the state. Because of law and order problem, the private sector investment also did not pick up compared to the potential of the state.

At the national level, agriculture plays a critical role in the economies of poor countries. In over half of the 48 nations designated as least developed countries (LDCs) by the United Nations, agriculture contributes more than 20 percent of the gross domestic product (GDP), and in 10 of them it accounts for over 40 percent of GDP (IFAD 2011b).6 Agriculture is also a major employer of rural labor in developing countries, often providing wage income to those who do not have any land or enough of their own to cultivate (Valdés et al. 2009). The Food and Agriculture Organisation (FAO) of the United Nations estimates that agriculture provides employment to 1.3 billion people around the world, 97 percent of whom live in developing countries (World Bank 2007).

It is worth mentioning that application of modern methods of agriculture is not seen in Assam and thus there is little scope of expanding employment opportunities in agriculture. But there is growing recognition that market-led diversification and enterprise development can broaden income opportunities and improve livelihoods for rural poor communities. According to Dhar, $\mathrm{P}$ K, (1994 Farmers sell to the nearest dealer/buyers, mostly immediately after harvesting when the price is at the lowest, instead of trying to find the best market for their products. From the Government side facilitating the marketing of agricultural products in Assam is less (Bhuyan, 1990; Bhuyan, et al., 1990). That does not attract the farmers to go for further up gradation their skills. If market linkage of agriculture products can be improved then there is a greater probability that the newer generations will be attracted towards agriculture and allied activities. This will contribute towards decreasing the negative effect of unemployment in the region.

Value-chain finance approaches can make an important contribution, though for a limited range of crops and farmers, and focused largely on credit. Beyond what general financial services can offer, there seem to be relatively few additional-though important-instances in which new delivery channels, products, or business models may be needed to address the specific risks and cash flows of agriculture.

\subsection{Rationale}

Assam's economy is fundamentally based on agriculture. Over 75 percent of the state's population relies on agriculture as farmers, as agricultural laborers, or both for their livelihood. While most other states in India are gradually moving away from their traditional agriculture-based economy toward industry or service-oriented economy, Assam is still heavily dependent on the agricultural sector (Phukan, A. K 1997).

According to the planning commission of India lack of markets and storage facilities is a major problem afflicting agriculture in Assam. It can be seen that Assam has in all only 34 regulated markets of all types, whereas Punjab has 667 such regulated markets and even Haryana has 273 as on 1995. The lack of marketing and storage facilities puts the farmers in Assam at a great disadvantage in comparison to their counterparts elsewhere in the country. With few markets to sell their output, farmers have little incentive to improve productivity and production by adopting modern farming techniques and increasing input use efficiency (Assam Development Report, 2007). 
International Journal of Managing Value and Supply Chains (IJMVSC) Vol.5, No. 1, March 2014

What prevents the rural producers specially the farmers from adding value to their product and have a strong role in the value chain is the concern at the moment. Therefore it is an interesting fact to look at whether the rural farmer/producer focused value chains can help rural populations to transition out of unemployment scenario by getting good profit of their product.

Access to formal credit is major hurdle of the poor. According to Mr. Vijay Mahajan (2005) micro credit or microfinance has been able to address the issues of the poor only peripherally. Therefore customized financial products are necessary in order to uplift the value chains. There is a scope for MFIs as well as for poor beneficiaries to develop their livelihood if proper attention is given in this aspect.

This paper is specially focused to explore those facts.

\subsection{Objectives of the Study}

This paper is an attempt to bring out the following objectives,

(i) To have a theoretical understanding of livelihood resources and its utilization for the sake of rural poor,

(ii) To understand the level of existing value chain practices of the livelihood resources,

(iii) To suggest a framework so that investment can be made on value chains to strengthen livelihood.

\subsection{Research Data and Methodology:}

The type of research is descriptive in nature. The scope of the study is confined to Assam only. The research is based on the conceptual framework of value chain and its impact on rural livelihoods, contributing to the development in the unemployment scenario of North East India in General and Assam as particular. The study is based on both primary as well as secondary data.

A study of a village from Sonitpur district of Assam is done. The village was selected by judgmental sampling. This study has covered 105 households in the selected village. The data were collected through structured schedule and interview. The data were analysed using simple statistical tools and packages of Microsoft Office Excel as well as SPSS. Findings are represented in tabular forms.

The secondary data is collected from books, research articles published in professional journals and other websites, government documents and websites. After collecting data, these were compared and analyzed in a suitable manner giving recommendations and conclusion.

\subsection{Livelihoods and Financing Value Chain - The Theoretical Framework}

Chambers and Conway (1992), the IDS (Institute of Development Studies) team's definition for livelihood is: "A livelihood comprises the capabilities, assets (including both material and social resources) and activities required for a means of living". Which literally means Livelihood is the means, activities, entitlements and assets by which people make a living. To develop the livelihood of a particular region, following factors or elements should be looked in to:Poverty reduction; Creation of working days, Well-being and capabilities (Chambers 1995; Sen 1984; 
Chambers 1989), Livelihood adaptation, vulnerability and resilience (Davies 1996), Natural resource base sustainability (Conway 1985, Holling1993). Livelihoods involve the use of assets in activities to give outputs, both to meet people's consumption requirements and to invest assets for the future (Andrew Dorward et.al. 2009).

According to the approach of Andrew Dorward and Nigel Poole (2003), and Shank (2004), livelihood should be analyzed from the perspective of how the poor integrate their assets and services into various economic activities to make products. Dorward et al., (2002) finds that there is often little attention to market systems and their roles in poverty reduction within the conceptualization and application of livelihood frameworks, or in professional fields such as agricultural research that seek to promote rural development. It is also seen that there is often less emphasis is given on market systems and markets linkeages and their role in poverty reduction (Albu and Griffith 2005).

On the other hand value chain denotes the activities that are performed to make a particular product reach its ultimate consumer from its conception. The importance that the value chain has in today's world is because of the fact that this is the particular field where the rural producers or farmers lack information resulting in getting lower income from their activity. They are not aware about the activities after production i.e. the market knowledge.

Dhar, P K, 1994 Explained that agricultural markets in Assam are under-developed. Geographical isolation, weak transportation and communication systems, poor marketing facilities, poor or nonexistent market intelligence (e.g., information on price and place to sell) are some of the principal marketing-related problems. In other parts of the world/country most of the brokers/buyers have access to modern communication facilities such as telephone internet and regular and timely market reports, farmers in Assam are many years away from having such facilities to gauge the market and sell accordingly. In terms of the role of government, earlier studies have shown that government efforts are more focused on collecting revenue (in the form of tax in the daily or weekly markets or through check-gates) than facilitating the marketing of agricultural products in Assam (Bhuyan, 1990; Bhuyan, et al., 1990).

It is now an established fact that markets are becoming a non accessible place for rural farmers that contribute to their lower level of income in the region. Some specific ways are necessary to identify channels and apply intervention and that particular channel regardless of individual or subsector chain. Unemployment issues can be minimized if the farmers focus more on their markets for the products.

Agriculture also provides a source of vitality and social welfare in rural communities that can mitigate urban shocks (World Bank 2007). Financing agricultural activities is challenging. Agriculture is by nature seasonal, with time passing between cash outflows and inflows. Currently most of the commercial banks have been favoring indirect rather than direct finance to agriculture. Finance to dealers, commission agents, NBFCs and SEBs, and investment in bonds earmarked for the priority sector have gained more priority than basic agricultural finance. This indirect finance will improve the infrastructure facilities in rural areas and create new services.

Agriculture sector continues to support more than 75 percent population of the State directly or indirectly providing employment of more than 53 percent of the total workforce (Economic Survey of Assam, 2012). An integrated and strategic approach is necessary in value chain 
International Journal of Managing Value and Supply Chains (IJMVSC) Vol.5, No. 1, March 2014

financing particularly in dealing with small scale enterprises. Financing alone may not be enough. In many cases, underlying issues are multi-dimensional and therefore solutions or strategies are also multi-dimensional or integrated. These include technical assistance to meet market requirements, private sector involvement, product differentiation, development of small scale producer groups, use of information and communications technology and effective coordination in the chain are essential in ensuring success. Moreover, these strategies are constrained if the enabling environment that includes policies and institutions is not conducive to the development of agricultural value chains.

The growth of the national economy since the mid nineties has not really percolated to the region in general and Assam in particular. Being delinked from the national growth spectrum, the need for enhanced governmental interventions in social and economic development in the State has been recognized as a necessity.

The traditional involvement in the agricultural sector has been declining day by day among the present generation of the youths of the State which implies attribution of shift of employment to the other sectors. Very few microfinance institutions have credit products for supporting basic livelihood activities in agriculture. Value chains in agriculture require different types of credit arrangements and to different types of organizations - not always households. At the household level production, investments in productive capacities and primary processing are feasible activities for which microfinance may be able to find answers. The present typical loan disbursement of Rs 10,000 will hardly support crop production in half an acre. This kind of financing will not support investments, primary processing or post-harvest holding of produce before marketing. The higher links in the value chain - such as processing, aggregation, storage, packaging, transport and retailing call for higher money outlays that are far beyond the MFIs' capacity to meet. Further the capacities to appraise such higher order investments in value chain activities beyond the primary level are very different; the risks associated with such financing are also higher and complex. I feel that Value chain financing and microfinance do not go well together.

If professionally organized value chains require small doses of finance at the primary end - small producer household - then Microfinance can have a financing role to play. There are well organized and managed value chains - BAIF (Gujarat, Maharashtra), PRADAN (Bihar, Jharkhand), CCD (Tamil Nadu), that have small producers at the root. Financing however had come from mainstream financial institutions - and not from MFIs. Gram and Indur Intideepam have a dairy producer company that has small dairy farmer at the base, of which some are financed by the Indur MACS.

If organizations promote value chains that provide access to markets for vulnerable (primary producer) households and employment to non-producer households, finance will flow in. Access to markets in itself has the capacity to attract finance. One need not limit financing in such a case to microfinance alone which is not the best option to support entire agricultural value chains.

\subsection{Value Chain and Market linkage for Development of Rural Masses}

In simple terms, value chain denotes the activities performed to produce a certain product and hand it over to the final consumer. Value chain refers to the full range of activities required to that are required to bring a product (or service) from conception through the different phases of 
production to delivery to the final consumers (Kaplinsky1999). So producers, processors, traders are an important part of value chain.

It is a known reality that rural producers are the initiator of most of the value chains. By helping them to capture the market, obtain fair returns, and produce higher-quality market demanded products improves rural incomes and employment and harnessing economic growth for rural areas.

In recent days, Value chain and the Market Development approach is getting very much interest. This approach is particularly suited to provide enterprise opportunities to rural masses, remote regions, and to the people involved in a particular sector or sub sector where the market knowledge is not developed. Whole value chain is analyzed for the region in order to make it an effective one (M4P approach)

Professionals of Development studies were long advocating for this approach to be implemented properly. One can find now many approaches which have the potential to be more appropriate and effective development tools: e.g. Value Chain and Market led Approaches, Making Market work for poor and Micro franchising. For example recently Business Houses and donors are focusing on approaches such as BoP. They invest substantial amount in these field.

It is suggested by many that that banks and other financial institutions such as MFIs should come up in terms of financing the value chains. Financing by MFIs for activities of the agriculture value chain is important as there are high possibilities. Financing the value chain would attract more and more people to the agri and artisan practices. Banks have an advantage over MFIs as they can undertake financing for higher links in the value chains like processing, aggregation, storage, packaging, transport and retailing. Over a few years, microfinance institutions are playing key role in providing credit products for supporting basic livelihood activities in agriculture.

Access to markets is not the only condition for rural masses to be able to sell their outputs. The availability of an adequate and communicative infrastructure is a basic condition for value chain development and upgrading. If the infrastructure is not strong then it hampers the flow of products to markets and bringing of market information in value chains.

\subsection{Findings}

The Balisiha Kachari village of Bihaguri block in sonitpur district of Assam consists of total 105 households. According to BPL Census (data available in Panchayat and rural development website of government of Assam http://pnrdassam.nic.in /bplsonitpur.htm) $71 \%$ of the household are beneficiary of BPL.

Therefore a little study was done to understand the livelihood scenario, the agricultural scenario and the role of value chain in popularizing agriculture in the village.

\subsection{Analysis and Findings:}

Some of the major findings related to their livelihood are presented in tabular form below. 
Table 1. Source of income

\begin{tabular}{|l|l|l|l|}
\hline Segment & No of individual & Segment & No of individual \\
\hline 1.Agriculture & 76 & 8.Fishery & 7 \\
\hline 2.Sale of egg & - & 9.Sale of poultry birds & 10 \\
\hline 3.Agri wage labour & 2 & 10.Piggery & 12 \\
\hline $\begin{array}{l}\text { 4.Sale of } \\
\text { goat/hen/bullock }\end{array}$ & 29 & 11.Sale of meat & 1 \\
\hline 5.Other wage labour & 55 & 12.Sericulture & - \\
\hline 6.Business & 38 & 13.Others(specify)/Service & 56 \\
\hline 7.Artisian & 18 & & \\
\hline
\end{tabular}

Most of the villagers are dependent on agriculture for their income. This is in the form of field crop, vegetables etc. The major part of the agriculture dependent masses is doing their cultivation in sharing. Artisan practices are there, but they do not consider it as their income generation activity which is quite dismal.

Table 2. Satisfaction with the return for the products (Agriculture)

\begin{tabular}{|l|l|}
\hline Satisfaction & Number \\
\hline Highly Satisfied & 5 \\
\hline Satisfied & 10 \\
\hline Neither Satisfied nor Dissatisfied & 28 \\
\hline Dissatisfied & 22 \\
\hline Highly Dissatisfied & 11 \\
\hline
\end{tabular}

The farmers who are taking up agriculture as their prime source of income opined negative about the returns they get. They do the traditional farming and sell the paddy to the village agents or in the near market. There is no practice of any kind of value addition.

Table 3. Place for selling agricultural output:

\begin{tabular}{|l|r|}
\hline Place of selling handicrafts products & \\
\hline & Number \\
\hline In The Village To the & 26 \\
Villager & 32 \\
In The Village To the Village & 18 \\
Trader & 76 \\
Use For Self Only & \\
Others & \\
Total &
\end{tabular}


International Journal of Managing Value and Supply Chains (IJMVSC) Vol.5, No. 1, March 2014

26 out of 54 household who practices agriculture informed that they sell their products to the villagers and 32 said that they sell to the village trader at a very lower rate. The others use it for their self purpose.

It is worth mentioning that the villagers by selling their outputs things have a very lower rate of satisfaction. The returns are low because of their lack of market knowledge.

To summarize, we noticed that the villagers were mostly engaged in agriculture for their livelihood (76). Very few are engaged in service and a few in government services. The people who are engaged in agriculture are more in number in the dis-satisfied side with their overall return. When asked about the reason of getting low return they replied that during the season they don't get access to a better market and end up selling to the middlemen itself to the village. Or they sell it to the nearest village market which is approximately 4 Kilo Meter away. Because of that fact many of the villagers are now not at all interested in making paddy farming for profit motives. They are doing for the sake of their legacy.

Very few products are sold to the markets. This clearly indicates their lack of access to the market and market knowledge. They are not happy with the returns as well. But they feel that the products are not demanded in the market which is not true.

Those products still have very good demand in the market and are highly priced when we go to a showroom. In reality the village people are unaware of the value of the products they are producing. There arises the need for their value chain knowledge.

\subsection{Conclusion:}

With the growing increase of globalization time has come to the people of Assam to cope up with the time and move forward with the changes. The regional difficulties are definitely there, but there is no denying the fact that these can be overcome. The region is not at all behind any other part of the country in any perspective, be it education or in resources. Even then there is always a question left for the development of the region. The region is full of resources but they are not at all utilized for the livelihood of the people. The mindset of the people is not production oriented, but they are keener on the survival factor. This mindset needs to be changed in order to get the best out of them. Creating a link of marketing channels and production sources will be always helpful in the region which is absent in most part of the region. People indulge in production always have the fear of not getting the right price.

The unemployment scenario in Assam reveals that there are a vast majority of rural people are self employed, but those portions are still fighting for their livelihood. Self employment is not giving them the return they should have earned. Mostly engaged in Agriculture related activities, the self employed masses if connected through a proper marketing channel with full utilization of the value chain, then there is a possibility that a large fraction will be motivated for entrepreneurial activity.

There is a growing decline in people involving in agriculture related activity noticed in the reports. People are moving to other sectors. That can be generalized as a case of non attraction due to lower returns. These lower returns can be improved by strengthening the market linkage and value chain. That can minimize the ever decreasing interest of the new generation for farm based activities. 
The study of the village also reveals those facts only. People practices handicrafts and farming, but mainly for consumption purposes, not for high scale production. Since the market is un accessible for them. Apart from that, the middlemen are taking the advantage of their less marketing knowledge and giving them low price.

In this regard, NERAMAC (North Eastern Regional Agricultural Marketing Corporation Limited) which is a specialized institute build for these prposes has a very big role to play in popularizing Agriculture or agro based business activities. They should not only focus on just do the marketing, they should also focus on making people market oriented and making them aware about the scenario. Those people, who are not attracted to the field of agriculture, can be attracted by showing them the roadmap towards success. More focus should be given on creating awareness among the rural people about the benefits of alternative practices like food processing, can help them achieve self sustainability.

If the youth are not interested in agriculture then they should be give practical market exposures so that they realize the price differences. Then their involvement in the value chain will also led to a positive scenario of sustainable income generation.

Therefore to make the existing livelihood practices as the main income generation activity for the people of this region, it needs a great effort in value chain enhancement. This in turn can contribute to the dismal scenario of unemployment. An approach can be taken up by the following way:

- Identification of micro activity

- Profitability Estimates of business plan

- Proper training of loan borrower in the line of accounts and marketing

- Backward and forward linkage of the activity

After proper scrutiny, microfinance for marketing of vegetable, fruits, cereals, flowers and horticulture produce can be extended in large volume. MFIs should look into interventions that can create links between small or primary producers and the upper value chain players.

\subsection{References}

- Bhuyan, S. A State intervention in agricultural marketing: Is it necessary? Agricultural Marketing, 33, 1 (April 1990):2-13.

- $\quad$ Bhuyan, S., H. Demaine, and K. E. Weber. "Market regulation or regulated market? The case of Assam, India," HSD Monograph no. 19, Asian Institute of Technology, Bangkok, Thailand, 1990.

- $\quad$ Bhuyan, S., S. D. Urs, and K. E. Weber. "Marketing farm produce: An efficiency test of traditional and regulated markets based on evidence from Assam, India." Economic Bulletin for Asia and the Pacific, 39, 2 (1988):46-55.

- Capacity Building and Technical Assistance Scheme, Annual Report 2008-09 Ministry of Development of North Eastern Region, pp 32-35 .

- Dhar, P. K. Axomor arthanitir ruprekha (The Economy of Assam). Kalyani Publishers: Ludhiana, 1994.

- Directorate of Employment and Craftsmen training, Assam

- Dolly S. (2008), Self Employment and Sustainable Development through SHGs - A MicroAnalysis of Women Empowerment in Select States of India.

- Employment and Unemployment Situation in India 2004-05 (Part - I) NSS 61st ROUND (July 2004 - June 2005) Report No. 515(61/10/1) September 2006, National Sample Survey Organisation Ministry of Statistics \& Programme Implementation Government of India 
International Journal of Managing Value and Supply Chains (IJMVSC) Vol.5, No. 1, March 2014

- Efficient Agricultural Marketing Author(s): Zaibun Y. Jasdanwalla Source: Economic and Political Weekly, Vol. 12, No. 53 (Dec. 31, 1977), pp. A133+A135-A140 Published by: Economic and Political Weekly Stable URL: http://www.jstor.org/stable/4366248 .

- Economic Survey of Assam 2012, Directorate of Economics and Statistics, Assam.

- Garikipati, Supriya (2008): "Agricultural Wage Work, Seasonal Migration and the Widening Gender Gap: Evidence from a Semi-arid Region of Andhra Pradesh", The European Journal of Development Research, 20(4): 629-48.

- ILO: Value Chain Development for Decent Work: A Guide for Development Practitioners, Governments and Private Sector Initiatives (Geneva: 2009) http://www.ilo.org/wcmsp5/groups/public/ed_emp/emp_ent/documents/instructionalmaterial/wcm s_115490.pdf

- Knutson, R. D., J.B. Penn, and Barry L. Flinchbaugh. Agricultural and Food Policy. 4th ed., Prentice Hall: Upper Saddle River, NJ, 1998.

- Levels of living and poverty patterns: a District-Wise analysis for india - Siladitya Chaudhuri, Nivedita Gupta Special Article, - Economic \& Political Weekly february 28, 2009 vol XLIV No 9.

- Phukan, A. K. (ed.). Axomor arthaniti, 1997 (The Economy of Assam, 1997). Buniyad: Guwahati, 1997.

- http://planningcommission.nic.in/plans/stateplan/index.php?state=sp_sdrassam.htm

- Prasad K. (2003), NGO's and Socio-Economic Development Opportunities, edition-I.

- Poverty Eradication / Alleviation in North East India : An Approach, Sponsored by, The North Eastern Council, Shillong, National Institute of Rural Development (Nird), North Eastern Regional Center (Nerc), Jawahar Nagar, Khanapara, Guwahati -Summary Report pp 12-14

- Razavi, Shahra (2009): "Engendering the Political Economy of Agrarian Change", Journal of Peasant Studies, 36(1): 197-226. 